\title{
LITERATURE RIVIEW \\ HUBUNGAN ANTARA PSIKOLOGI DAN SPIRITUAL DENGAN KUALITAS HIDUP PASIEN KANKER PAYUDARA
}

\author{
*Popy Irawati \\ Email : popyners@gmail.com
}

\begin{abstract}
Abstrak
Kejadian sakit merupaka kejadian yang selalu dianggap buruk dan merugikan dalam mempertahakan kualitas hidup. Kebutuhan spiritual berhubungan dengan peningkatan kualitas hidup manusia yang merupakan tujuan penting dalam tatanan klinik (Balbony at all, 2007)

Salah satu pemicu kejadian kanker adalah stress dan kecemasan yang terjadi dalam waktu yang lama, hal tersebut juga dapat memperberat penyakit yang telah terdiagnosis. makalah ini akan menelaah beberapa literature yang mengemukakan tentang penelitian yang dilakukan pada pasien kanker payudara tentang bagaimana peran psikologi dan spiritual terhadap perkembangan penyakit kanker, yang dilakukan pada saat diberikan terapi dan setelah selesai melaksanakan program terapi. Tujuan studi ini adalah menelaah literature untuk mengetahui hubungan antara psikologi dan spiritual dengan kualitas hidup pasien kanker payudara.

Disain studi dalam penelitian ini adalah menggabungkan literature yang mempunyai arahan yang sama yang diunduh dari Cinahl dan Proquest untuk mempelajari hubungan antara psikologi dan spiritual dengan kualitas hidup pasien kanker payudara. Empat literature yang kami temukan terdiri dari 3 literature kuantitatif dan 1 literatur kualitatif.

Hasil penelitian menunjukkan bahwa program MBSR secara significan dapat menurunkan tingkat stress pada penderita kanker payudara dengan nilai yang sinifikan pada kecemasan, takut kekambuhan dan tanda depresi. Factor spiritual dan religi merupakan factor yang sangat mendukung terhadap peningkatan kualitas hidup pasien dengan kanker payudara. Social support juga merupakan factor yang secara signifikan mendukung meningkatkan optimism yang pada akhirnya meningkatkan kulaitas hidup pasien dengan kanker payudara.
\end{abstract}

\section{Kata Kunci : Hubungan Psikologi Dan Spiritual, Kualitas hidup, kanker payudara}

*) Dosen STIKes 'Aisyiyah Bandung 


\section{Pendahuluan}

Aspek spiritual merupakan salah satu aspek dalam kehidupan manusia yang sangatberperan dalam memberikan arti dalam setiap kejadian baik atau buruk. Kejadian sakit merupaka kejadian yang selalu dianggap buruk dan merugikan dalam mempertahakan kualitas hidup. Kebutuhan spiritual berhubungan dengan peningkatan kualitas hidup manusia yang merupakan tujuan penting dalam tatanan klinik (Balbony at all, 2007)

Kanker merupakan penyakit mematikan kedua setelah penyakit kardiovaskuler, kelangsungan hidup penderita kanker cukup besar tergantung pada deteksi dini dan tindakan pengobatan (Vachani at all, 2011). Salah satu pemicu kejadian kanker adalah stress dan kecemasan yang terjadi dalam waktu yang lama, hal tersebut juga dapat memperberat penyakit yang telah terdiagnosis . makalah ini akan menelaah beberapa literature yang mengemukakan tentang penelitian yang dilakukan pada pasien kanker payudara tentang bagaimana peran psikologi dan spiritual terhadap perkembangan penyakit kanker, yang dilakukan pada saat diberikan terapi dan setelah selesai melaksanakan program terapi.

\section{Metode Penelitian}

Studi ini dilakukan dengan menelaah 4 penelitian tetang hubungan psikolgi dan spiritual dengan kualitas hidup penderita kanker payudara yang diambil dari Cinahl databased dan jurnal lainnya yang mendukung .

Jenis penelitian yang didapatkan terdiri dari penelitian kualitatif dan penelitian kuantitatif yaitu randomized controlled trial, kohort dan cross sectional yang mempunyai tujuan penelitian yang selaras dengan penelitian yang di telaan oleh penulis.

\section{Hasil Penelitian dan Pembahasan}

Empat artikel yang di publikasikan yang membahas hasil penelitian yang terkait dengan judul hubungan antara aspek psikologikal dan spiritual pada pasien kanker payudara dengan kualitas hidup terdiri dari 1 penelitian kualitatif dan 3 penelitian kuantitatif yang terdiri 
dari randomized controlled trial, kohort dan cross sectional .

Tahun 2009 ,lengatcher dkk. Melakukan penelitian dengan menggunakanprogram Mindfullbased stress reduction untuk menilai tingkat stress, kecemasan, takut dan depresi pada pasien kanker payudara yang selesai menjalani pengobatan, Menurut lengatcher dkk, dampak psikologis dan emosional yang ditimbulkan oleh proses penyakit dan pengobatannya dapat di turunkan dengan menggunakan terapi komplementer atau terapi alternative diantaranya dengan melatih kemampuan diri dalam mengendalikan stress dan fakktor psikologis lain salah satunya adal;ah MBSR

MBSR adalah yaitu program yang dilaksanakan selama 6 minggu yang mengandung 3 komponen secara spesifik yaitu berhubungan dengan relaksasi,.meditasi dan koneksi tubuh-pikiran, kedua praktek meditasi dan tugas atau pekerjaan rumah ,ketiga diskusi tentang hambatan relaksasi. MBSR diyakini dapat memperbaiki psikologikal dan tanda fisik serta kualitas hidup pada kanker payudara pada periode survive.

Setelah dilakukan intervensi selama 6 mg dalam kelas, kemudian akan di evaluasi dengan menggunakan instrument yang telah divalidasi dan inventory penilaian tentang takut akan kekambuhan dilakukan dengan menggunakan 30 item pertanyaan untuk mengukur skala kekambuhan dan ketakutan yang normal pada wanita yang mengalami kemungkinan kekambuhan kanker payudara, untuk mengukur Kecemasan digunakan 20item masing-masing untuk state dan trait anxiety dengan nilai tertinggi mengindikasikan kecemasan yang berlebihan, tanda depresi diukur dengan 20 item pertanyaan yang berasal dari skala depresi dari studi epidemiologi dengan indikasi nilai tertinggi untuk depresi. Selain daripada itu penelitian ini juga mengukur tingkat optimism dari partisipan dengan 6 item pertanyaan tetang tes orientasi kehidupan dengan expectasi tujuan hidup positif atau negative, nilai tertinggi dari aspek ini mengindikasikan optimisme yang 
lebih baik. Demikian juga dengan pengukuran dukungan social , spiritual dan kualitas hidup

Hasil yang didapatkan adalah nilai yang dihasilkan dengan membandingkan antara kelompok intervensi dan kelompok control yaitu ada perbedaan yang signifikan yang menunjukan adanya perbaikan tingkat kecemasan (30.4 vs $34.5 \mathrm{p}=$ $0.004)$, takut (9.3 vs $11.6, \mathrm{p}=0.007)$ dan depresi (6.3vs 9.6, $\mathrm{p}=0.03$ ) hasil ini disertai dengan penilaian Quality of life (QOL) melalui penilaia fungsi fisik 50.1 vs $47.0, \mathrm{p}=$ $0.01)$, dan peningkatan energy $(53,5$ vs 49.2, $\mathrm{p}=0.02$ ).

Kesimpulan yang diambil dari penelitian ini adalah program MBSR secara significant dapat memperbaiki distress posikologi, ketakutan akan kekambuhan dan kualitas hidup pada kanker payudara yang telah selesai melakukan pengobatan (lengacher et al , 2009)

Dua Literature lain mengatakan bahwa aspek spiritual juga ikut serta dalam menentukan status psikologikal pasien.yaitu penelitian yang dilakukan oleh Harandy dkk(2008) dan Balboni dkk,
(2007). Harandy dkk. menggunakan metoda kualitatif yang dilakukan pada pasien kanker payudara yang telah selesai menjalani pengobatan. Melalui wawancara mendalam yang dilakukan peneliti terhadap 39 wanita Muslim berkebangsaanIran yang menderita kanker payu dara dan telah selasai menjalani pengobatan didapatkan kesimpulan bahwa mekanisme koping yang terbentuk didasarkan pada keyakinan yang kuat terhadap sesuatu (dalam hal ini Tuhan) sehingga perlawanan yang dilakukan terhadap masalah yang dihadapi akan menjadi lebih efektif seperti yang terjadi pada hampir semua partisipan penelitian ini, kanker yang mereka alami dijadikan sebagai salah satu ujian yang diberikan tuhan dan berusaha mngambil hikmah dari ujian yang diberikan tanpa menghilangkan usaha pengobatan yang harus dilakukan melalui pengobatan medis modern atau pengobatan alternative.

$$
\text { Penelitian lain yang }
$$
mendukung kepada kesimpulan diatas adalah penelitian yang dilakukan di Amerika Serikat oleh Balboni dkk (2007) yang 
menyatakan bahwa dukungan spiritual berhubungan dengan kualitas hidup yang lebih baik, dan keyakinan individu merupakan hal yang paling berperan dalam mempertahankan kehidupan.

Seperti halnya penelitian diatas partisipan dalam penelitian ini adalah wanita dengan kanker payudara yang di rekrut mulai tanggal 1 agustus 2002 sampai dengan 25 agustus 2005 akan tetapi kriteria sampel pada penelitian ini menekankan pada stadium akhir dari kanker payudara. Dasar penelitian ini adalah konsep mengenai religi dan spirituality yang dikaitkan dengan keberhasilan pengobatan kanker dalam meningkatkan kualitas kehidupan, dengan kata lain religi dan dukungan spiritual yang tinggi dapat memperbaiki kualitas hidup dan mekanisme koping dan sebaliknya apabila tidak ada dukungan spiritual dan religi yang rendah dapat meningkatkan kesakitan dan menurunkan kualitas hidup (Balboni dkk. 2007).

Metoda yang dipakai pada penelitian ini adalan wawancara yang dilakukan untuk mengetahui religi dan spiritual sebelum dan setelah didiagnosis kanker yang kemudian dianalisis dengan regresi liner statistic yang menghasilkan 156 (61\%) , partisipan menyatakan bahwa religi merupakan hal yang sangat penting, $47 \quad(20 \%)$ menyatakan cukup penting dan 27 (27\%) menyatakan tidak penting.

Penelitian lain yang dilakukan oleh Matthews and cook (2008) yang menelaah tentang hubungan sikap optimis dengan keadan emosional, koping, keyakinan dan dukungan social pada wanita yang sedang melakukan pengobatan untuk kanker payudara menyatakan bahwa efek positif dari optimis pada emosi yang baik diperantarai oleh tingkat keyakinan seseorang terhadap Tuhan atau yang dipercayainya, optimism juga berhubungan dengan dukungan social tetapi emosional yang baik tidak berhubungan dengan dukungan social,sedangkan antara optimism, emosi dengan problem focus coping tidak ada hubungan yang signifikan

Penelitian ini dilakukan pada 93 wanita dengan kanker payudara stadium I-IV dengan usia antara 39 79 dan sedang menggunakan terapi 
radiasi. Instrument yang digunakan pada pnelitian in adalah the positive Affect scale dari positif dan negative affect schedule yang telah valid dan reliable, Life orientation test (LOT), Social Support questionarre (SSQ), The Jallowiec coping scale, Self Transendence scale (STS) dan The symptom distress scale (SDS).

Dari Hasil penelitian skor optimism antara 0-33 $(\mathrm{M}=21.87 \mathrm{SD}$ $=6,02)$ lebih rendah dari penelitian yang dilakukan pada tersangka kanker payudara. Skor ppada wanita yang dicurigani kanker payudara mungkin akan tinggi karena belum ada kepastian akan diagnosis yang sebenarnya (Mathew and cook, 2008).Sedangkan hasil pengukuran faktor mediator dilakukan dengan analisi regresi kontrol dengan aturan secara statistic dinilai signifikan apabila $F(1.90)=18.0, p<0.001$.

Kesimpulan yang dapat diambil pada penelitian ini adalah sikap optimis akan tergantung pada tingkat keyakinan atau religi seseorang , dukungan social disekitarnya sehingga dapat menghadilkan emosi yang sejahtera, dalam arti pada wanita dengan kanker payudara dibutuhkan tingkat keyakinan yang tinggi dan dukungan social yang besar sehingga wanita tersebut mempunyai sikap optimis dan emosi yang sejahtera atau baik dalam menjalani proses pengobatan kanker payudara.

\section{Simpulan}

Tiga dari empat penelitian diatas dilakukan pada wanita dengan kanker payudara yang telah selesai menjalani pengobatan dan hanya satu penelitian yang melakukan pada wanita yang sedang menjalani pengobatan, dengan kata lain penelitian ini dilakukan sebagian besar pada pasien yang relative telah berhasil selamat dan memperpanjang harapan hidup setelah menjalani proses pengobatan .

Hubungan antara factor psikologi dan spiritual dengan kualitas hidup pada pasien kanker payudara mempunyai factor yang kompleks dan bervariasi, namun dari hasil penelitian diatas dapat disimpulkan bahwa factor psikologis yang terdiri stress, takut akan kekambuhan kecemasan dan depresi merupakan hal sering dirasakan oleh 
penderita kanker payudara selain gangguan pada fisik ,baik yang sedang dalam proses pengobatan maupun yang telah selesai dalam tahapan pengobatan ,akan tetapi hal tersebut dapat di reduksi atau dihilangkan dengan menggunakan program yang signifikan dapat memperbaiki psikologi pasien, dalam literature diatas disebut MBSR sehingga dapat berangsur berubah menjadi kedaan yang optimis dengan tingkat emosional yang sejahtera akan tetapi bukan hanya program MBSR saja melainkan factor lainpun ikut mendukung kedaan optimism tersebut yaitu dukungan social dan self trancendense atau situasi spiritual dan religi dari pasien tersebut. Hal tersebut dapat digambarkan dengan bagan dibawah ini :
Input
Proses
Output

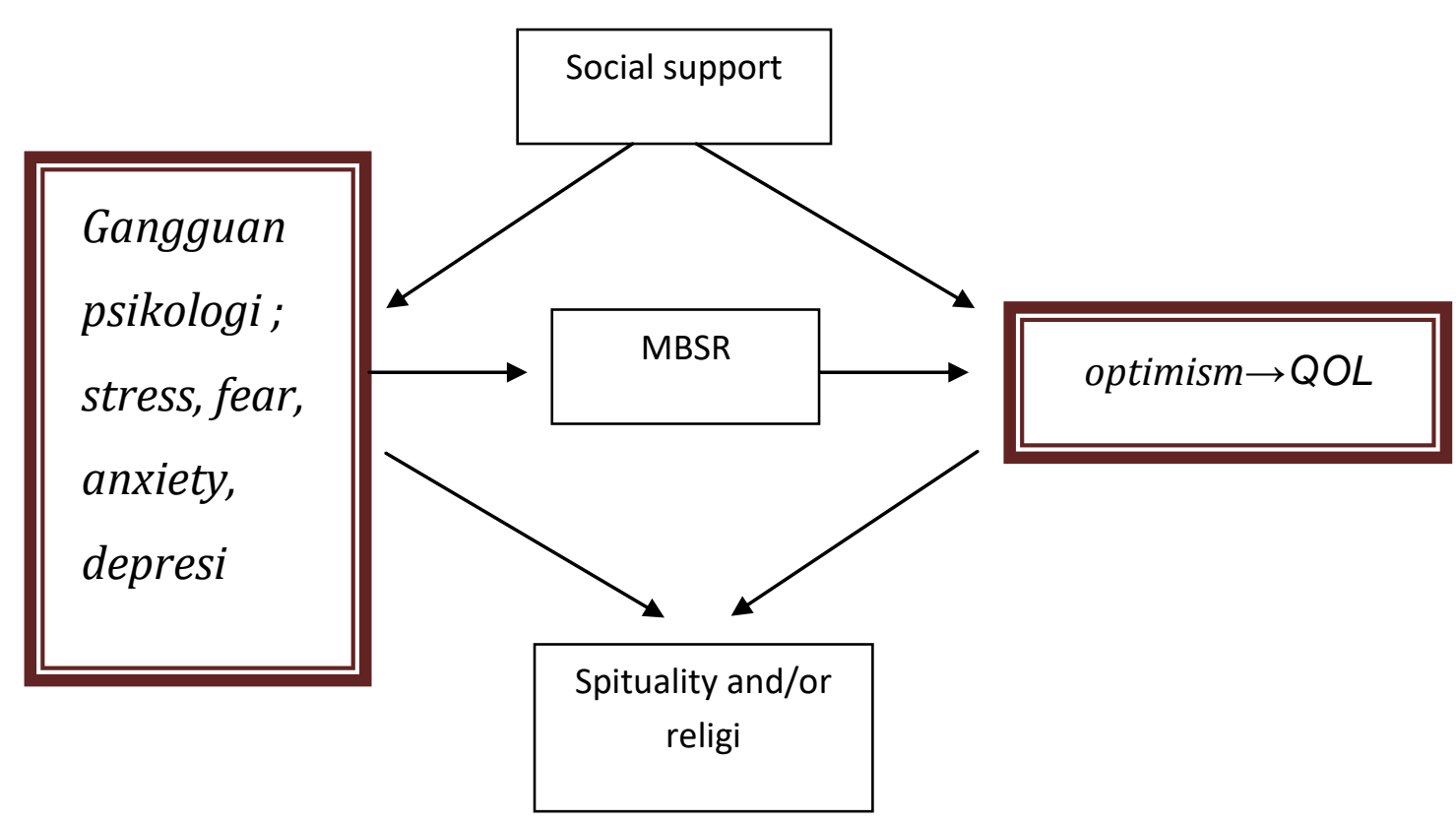

Gambar 1. Hubungan psikologi dan spiritual dengan kualitas hidup pada kanker payudara 


\section{Daftar Pustaka}

Balboni, Vanderwerker, Block et al., 2007, Religiousness ang Spiritual Support Among Advanced Cancer Patiants and Assosiations with End of life treatment Preference and Quality of Life, Journal Clinical Oncology, vol 25.number 5, February 2007, diakses tanggal 15 April 2013

http://web.ebscohost.com/ehost/resultsa dvanced?sid=703ecae4-5b4c-441592f7-

4a3aba22166e\%40sessionmgr4\&vi $\mathrm{d}=15 \&$ hid $=7 \&$ bquery $=($ Breast + can cer)+and+(interventions)\&bdata $=\mathrm{J}$ mRiPWM4aCZjbGkwPUZUJmNs djA9WSZjbGkxPVBUMSZjbHYx PVkmdHlwZT0xJnNpdGU9ZWhv c3QtbGl2ZQ\%3d\%3d

Harandy,Ghofranipour, Montazery, Anoosheh et al. 2008. Muslim Breast Cancer Survivor Spirituality: coping strategy or health seeking behavior hindrance, Health Care for Women International, 31:88-98, 2010, diakses tanggal 15 April 2013

Lengatcher, Mallard, White, et al, 2009, Randomized Contrlled Trial of Mindfulness- Based Stress Reduction (MBSR) for survivors of breast Cancer, psycho-oncology 18 : 1261-1272,2009, in Willey Interscience, Diakses tanggal 25 April 2013 http://web.ebscohost.com/ehost/pdfview er/pdfviewer?vid=11\&hid=104\&si $\mathrm{d}=703$ ecae4-5b4c-4415-92f74a3aba22166e\%40sessionmgr4

Mathews and Cook, 2008, Relationships among optimism, wellbeing, self transendece, coping and secial support in women during treatment for breast cancer, psycho-oncology 18 : 716-726, 2009 in Willey Interscience, diakses tanggal 17 April 2013

Vachani, Di Lullo, Hamshire et al, 2011, Preparing Patients For Life After Cancer Treatment, American Journal Nursing, April 2011, Vol 111, no. 4 diakses tanggal 13 Mei 2013 